Economic considerations aside, in inviting comparison between her work and Hosseini's, they have done her a disservice.

\title{
References
}

Brontë, C. (1847): Jane Eyre. London: Penguin, 2006.

Brontë, E. (1847): Wuthering Heights. London: Penguin, 1995.

Busfield, Andrea (2009): Born Under a Million Shadows. London: Black Swan.

Gilbert, S.M. and Gubar, S. (1979): The Madwoman in the Attic. Second Edition. New Haven and London: Yale UP, 2000.

Hosseini, Khaled (2003): The Kite Runner. London: Bloomsbury. . (2007): A Thousand Splendid Suns. London: Bloomsbury.

Smith, David (2009): “The Upside of Afghanistan” The Observer 19 April.

Spain's Long Shadow: The Black Legend, Off-Whiteness, and Anglo-American Empire. María DeGuzmán. Minneapolis: University of Minnesota Press, 2005. Pp. ix +372.

Reviewed by Jenny Heil

Emory University

Scholars have attempted to de-center the United States from American Studies in recent years by studying instead the phenomenon of the shadow, whether cast by an Anglocentric United States onto other nationalities or vice versa, in an effort to complicate ideas about nationalism and to promote better understandings of hemispheric and/or transatlantic interactions. María DeGuzmán's monograph Spain's Long Shadow: The Black Legend, Off-Whiteness, and Anglo-American Empire participates in this turn in what she calls the New Americas studies by destabilizing the traditional black/white racial binary to reveal how an Anglo-American imperial identity has been mediated across the Atlantic through U.S. representations of Spain as not-quite-white. She sketches the history of this off-whiteness from the late eighteenth century to the twenty-first by exploring the implications of how and why the two major forms racializations of Spain took - the alien white darkened by the Black Legend and the Orientalized racial other-change over time. DeGuzmán appropriates the metaphor of the long shadow not only to describe Spain's historically imperial past (as indicated by the book's main title Spain 's Long Shadow) but more importantly to underline how artists conceived of the U.S.'s own emergent empire in contradistinction to Spain's supposedly more brutal one (indicated by the subtitle The Black Legend, Off-Whiteness, and Anglo-American Empire). By focusing largely on canonical U.S. writers' representations of Spain, particularly in the first four of six chapters, DeGuzmán does not de-center the United States from this New Americas studies monograph, but she does use that focus to problematize notions of "America" that equate it with the territorial United States and to historicize how the U.S. came to be at the center of American Studies in the first place. Indeed, one of the assets of this monograph is that DeGuzmán foregoes a study of the "Hispanophile" authors (i.e., Washington Irving, 
William H. Prescott, George Ticknor), which one would typically expect from studies of Hispanism in the U.S., to reveal how entrenched Spain was in the imagination of other U.S. writers who have not hitherto been considered part of this movement.

In order to elaborate a more nuanced formulation of Anglo-American (imperial) identity, DeGuzmán relies on the psychoanalytic concept of the imago or alter ego, of which Spain is that "image in the mirror, as a rival idealized and therefore demonic body" in contrast to the more benignly figured American, that is Anglo-U.S., ego (xvii). As Spain's gubernatorial power in the Americas declined during the nineteenth century, its symbolic power in North America as imperial alter ego increased, and DeGuzmán traces this development in chapters organized by chronology and pseudo- to outright-racializations of things "Spanish." Prior to the late nineteenth-century consolidation of an Anglo-American imperial identity with the U.S. defeat of Spain during the Spanish-Cuban-American War, which DeGuzmán discusses in chapter three, a still-fluid Anglo-American identity cohered around two ideas of Spain: the alien white conquistador/knight/discoverer and the Moor/Gypsy/Indian racial other, which DeGuzmán discusses respectively in chapters one and two. Through close readings in chapter one of Charles Brockden Brown's Wieland, Edgar Allan Poe's "William Wilson" and "The Pit and the Pendulum," and Herman Melville's Benito Cereno, DeGuzmán shows how early nineteenth-century "American" fiction in the Gothic mode deployed the Black Legend, which posited that the Spanish colonial project was more nefarious than that of England, to morally blacken Spaniards in a proto-racialization that did not become separated from AngloAmericanness until the latter part of the nineteenth century as tensions rose between Spain and the U.S. over Cuban territory. By analyzing in chapter two the historical romances The Yemassee by William Gilmore Simms, The Scarlet Letter by Nathaniel Hawthorne, Elsie Venner by Oliver Wendell Holmes, and the iconic El Jaleo by John Singer Sargent, DeGuzmán shows how by the mid-nineteenth century, Spain's ethnically mixed past in Europe and in the Americas (among Moors, Gypsies, Jews, Native Americans, and Africans), became a threatening presence against which justifications for a more ethnically pure U.S. expansion were made. Chapter three incorporates gender and class into this study of how race, by the close of the nineteenth century, more virulently factored in the compounding of a U.S. empire. DeGuzmán discusses how people of all classes, and women in publicly recognized roles, were subdued as potential threats to the internal order of the U.S. by co-optation into its imperial cause against the external enemy: Spain.

Particularly strong is chapter four in which DeGuzmán examines early twentieth-century representations of Spain by Gertrude Stein, Ernest Hemingway, and Richard Wright to argue convincingly for its totemic influence on the Modernist movement, thereby revising accounts of Modernism that more usually study France's influence on U.S. authors. Chapters five and six take this study through the second half of the twentieth century by focusing on the fiction, photography and film of Kathy Acker, Xurxo Lobato, Fernando Colomo, and Floyd Salas, among others, not only to reveal how the Spaniard figured as alien white and Oriental other became tied together in intricate ways but also to show that such complicated figurations of Spain are sometimes - but not always - deployed to deconstruct nationality as essentialized identity itself.

From the site of a prior and problematic Spanish imperialism (before the period of this 
study), to a waning empire figured as alter ego to a waxing U.S. empire (during the nineteenth century), to a vanquished other with whom postcolonials have begun to identify (during the twentieth century), DeGuzmán shows that despite such late-twentieth century identifications with Spain, "the recycling of certain kinds of figurations of Spain in the mid-1990s symptomatizes the cycling and continued life of empire, in this case Anglo-American imperial ideology" (303). While this argument appears, at times, to overdetermine DeGuzmán's analysis, the strength of Spain's Long Shadow lies not only in lucid close readings of such literary texts as Stein's Autobiography of Alice B. Toklas, The Geographical History of America, and Paris France but also in its insight into other media, such as paintings, photography and political cartoons. Moreover, DeGuzmán's work exemplifies the potential of interdisciplinary scholarship, particularly between American and Latina/o Studies, for which Spain 's Long Shadow is a helpful foundation. With her intervention, American Studies scholars can no longer ignore or deny the central importance of Spain to the history and continuing development of an Anglo-American imperialism.

\section{The Edgar Allan Poe Review. FALL 2009 VOLUME X, NUMBER 2}

Reviewed by Silvia Molina

Polytechnic University of Madrid

Funded by the "Poe Studies Association" and printed at Saint Joseph's University (Pennsylvania, USA), The Edgar Allan Poe Review contains in its Fall 2009 issue a series of interesting and enlightening essays written on the occasion of the bicentennial which commemorates the birth of Edgar Allan Poe. Margarita Rigal and Beatriz González act in this issue as guest editors for the "Spanish" essays.

The part of issue edited by Rigal and González opens with a section entitled Poe in Spain on the Occasion of His Bicentennial and includes two essays that link Poe with two Victorian writers. The first one, Plagiarism in Poe: Revisiting the Poe-Dickens relationship by Fernando Galván highlights the influence Dickens' works exerted on Poe's theory of the short story, the unity of effect and on some of Poe's well-known works such as "The Tell-Tale Heart", "The Black Cat", "Ligeia” or the famous poem "The Raven" among others. The latter is fairly similar to Barnaby Rudge. In Dickens' novel we can read the description of the link between the mentally retarded Barnaby and his raven, "Grip", both living at the Newgate prison. Galván finds other echoes in Poe's "the Raven" such as the repetition of the raven's words, the repetition of "hope", the reference to melancholy, etc. However, Galván clearly points out that this does not strictly mean plagiarism. The ideas and motifs that shape "The Raven" have their origins in Dickens but "Poe managed somehow to develop and improve them in his unforgettable poem" (page 19). Galván proves with other well chosen examples from the tales and the poems that Poe was certainly sensitive to some of Dickens's ideas, narrative constructions and rhetorical and stylistic aspects. Galván concludes in his thoughtprovoking study that Poe created new works sometimes superior to his sources and that means " a conscious, careful and patient combination of a diversity of materials and techniques, 